\title{
K REFORMĚ ÚZEMNĚ SPRÁVNÍHO ČLENĚNÍ ČESKÉ REPUBLIKY
}

\author{
MARTIN WAGNER
}

\begin{abstract}
The Reform of the Territorial Administrative Structure of the Czech Republic
The territorial administrative structure of the Czech Republic has been reformed by Act No. 51/2020 Sb. This change implements an integrated system of local administrative units for the performance of the state administration on different levels based on local units defined as micro-regions. The new arrangement respects the existing boarders of territorial self-governing units while provides an abolishment of the old system of administrative regions based on Act No. 36/1960 Sb.
\end{abstract}

Keywords: administrative territorial structures; region; district

Klíčová slova: územně správní členění státu; kraj; okres

DOI: $10.14712 / 23366478.2021 .41$

\section{1. ÚVOD}

Rok 2020 přinesl vedle vážných komplikací, spojených s bojem proti koronavirové pandemii, rovněž nový zákon o územně správním členění státu. Jako zákon č. 51/2020 Sb. vstoupil v účinnost počátkem ledna letošního roku, aniž by mu odborná veřejnost věnovala větší pozornost. Tento prŕíspěvek se otázky spojené se (staro)novým územním členěním pokusí dostat více do popředí. Nový zákon nepředstavuje žádnou revoluci v územní organizaci státní správy. V mnohém navazuje na předešlé a přizpůsobuje uspořádání, vzešlé z předchozí úpravy zákonem č. 36/1960Sb., o územním členění státu, která s úlohou územní samosprávy vůbec nepočítala, současným podmínkám všeobecné územní státní správy, přenesené zejména na orgány vyšších územních samosprávných celků a obcí s rozšířenou působností.

Na úvod je třeba vytknout před závorku samotný smysl všeobecného územně správního členění: jeho existence je samým předpokladem pro výstavbu veřejné správy na tradičním územním principu. ${ }^{1} \mathrm{~K}$ efektivitě výkonu zejména státní správy nepochybně př́spívá, jsou-li její různé agendy vykonávány ve v zásadě neměnných správních ob-

1 Srov. HENDRYCH, D. Správni věda: teorie veřejné správy. 4. vyd. Praha: Wolters Kluwer, 2014, s. 118. 
vodech. Velká rozrůzněnost územní působnosti správních úřadů, ${ }^{2}$ at již jako př́mých, nebo nepř́mých vykonavatelů státní správy, naproti tomu jednak ztěžuje spolupráci mezi nimi navzájem, jednak nepochybně komplikuje situaci jejím adresátům, zejména působí-li na jednotlivce $\mathrm{z}$ různě vzdálených sídel. Obojí se s jistotou prříći principům dobré správy a ve svém důsledku i zákonnému požadavku vzájemné součinnosti mezi správními orgány. ${ }^{3}$ Je třeba mít současně na paměti, že adresát veřejné správy zásadně nerozlišuje mezi správou vykonávanou jejími nositeli odlišnými od státu a správou prováděnou správními úřady státu, třebaže vertikálně dekoncentrovanými. Relativně jednotná a úplná struktura územního členění je proto v moderní veřejné správě žádoucí. Územní členění státu ve své podstatě představuje zpravidla vícestupňový systém správních obvodů. V organizačním zákonodárství lze pak na obvody již existujících územních celkủ toliko odkázat, aniž by bylo třeba vytvářet ad hoc systém územního členění pro každý obor veřejné správy. Správní obvod je pak ve své podstatě jen územně vymezenou působností pro výkon státní správy. ${ }^{4}$ Bezpochyby však vždy záleží na úvaze zákonodárce, nakolik využije soustavu územního členění státu při organizaci územní působnosti jednotlivých správních úřadů.

\section{NOVODOBÝ VÝVOJ ÚZEMNÍHO ČLENĚNÍ ČESKÉ REPUBLIKY A JEHO NEDOSTATKY}

Nový zákon s nemalým zpožděním pomyslně uzavírá reformu územní veřejné správy z přelomu tisíciletí. Stojí za připomenutí její hlavní milníky: ústavním zákonem č. 347/1997 Sb. došlo k vytvoření čtrnácti vyšších územních samosprávných celků. Reálného naplnění se tento stupeň územní (regionální) veřejné správy dočkal teprve přijetím krajského zřízení zákonem č. 129/2000 Sb. Reorganizace všeobecné územní státní správy pak následovala sadou zákonů (zákony č. 311-320/2000 Sb.), cestou zrušení okresních úřadů a přenosem jejich všeobecné působnosti zejména na tehdy zríizené obecní úřady obcí s rozšířenou působností, jejichž výčet (vedle obcí s pověřeným obecním úřadem) nově stanovil zákon č. 314/2002 Sb. ${ }^{5}$

Tehdejší změny tedy uvedly v život kraje coby vyšší územní samosprávné celky a prohloubily realizaci tzv. smíšeného modelu veřejné správy, ${ }^{6} \mathrm{v}$ němž podstatnou část územní státní správy vykonávají jako přenesenou působnost ve vlastních správních

2 Zde míněn správní úřad v institucionálním pojetí; srov. HENDRYCH, D. a kol. Správní právo: obecná část. 9. vyd. Praha: C. H. Beck, 2016, s. 67.

3 Srov. ust. $\S 8$ odst. 2 zákona č. 500/2004 Sb., správní rád.

4 HENDRYCH, D. a kol. Ústava České republiky: komentár. Praha: C. H. Beck, 1997, s. 176.

5 Jednalo se o tzv. II. fázi reformy územní veřejné správy - viz ELIÁŠ, A. II. fáze územní reformy. Deník veřjné správy [online]. 9. 11. 2020 [cit. 2021-05-23]. Dostupné na: http://www.dvs.cz/clanek.asp?id=73446.

6 PRŮCHA, P. K otázkám organizace současné místní a regionální samosprávy. In: NECKÁR̆, J. - RADVAN, M. - SEHNÁLEK, D. - VALDHANS, J. (eds.). Dny práva - 2008 - Days of Law: 2. ročník mezinárodni konference pořádané Právnickou fakultou Masarykovy univerzity / the second year of the international conference held by Masaryk University, Faculty of Law: 4.-5. 11. 2008. Brno: Masarykova univerzita, 2008, s. $1582-1595$. 
obvodech obecní úřady obcí tř́ typů. ${ }^{7}$ Ačkoli se při zrrízení obecních úřadů obcí s rozširrenou působností původně počítalo přirozeně se zánikem zastaralé soustavy administrativních okresů a krajů, $\mathrm{k}$ jejich zrušení nakonec zákonodárce nepřistoupil, zejména s ohledem na doposud existující územní organizaci správy sociálního zabezpečení, způsob vymezení obvodů krajských hygienických stanic a v neposlední řadě i s ohledem na organizaci justice. ${ }^{8}$

Dědictvím v tomto smyslu nedokončené reformy tak zůstaly dva vzájemně neskladebné systémy územního členění státu, starý a nový. Do konce roku 2020 proto platilo, že vedle třinácti samosprávných krajů de iure existovalo i nadále sedm krajů zřízených již zákonem č. 36/1960 Sb., s tím, že území okresů, jimiž bylo území samosprávných i administrativních krajů ze zákona definováno, ${ }^{9}$ často současně náleželo do dvou odlišných typů krajů, spravovaných z odlišných sídel. ${ }^{10}$ Vzájemná neskladebnost se projevovala zároveň u správních obvodů obcí s rozšriřenou působností, jejichž území se často rozkládalo na území více okresů zároveň. ${ }^{11}$ Hranice územních jednotek nižšího stupně tedy v mnoha př́ípadech přesahovaly hranice těch vyšších. Neblahý vliv na celkovou srozumitelnost tohoto uspořádání měla nadto samotná existence dvou typů územních celků, nazývaných shodně jako „kraj““.

Zákon č. 36/1960 Sb., o územním členění státu, se přitom přinejmenším ohledně úpravy sedmi administrativních krajů stal zčásti obsoletním, nebot' správní úřady s všeobecnou působností na jejich půdorysu neexistují již od roku 1990 a organizace specializované státní správy se po vzniku vyšších územních samosprávných celků přizpůsobila tomuto novému mezoregionálnímu článku, ${ }^{12}$ jakkoli i tento proces byl spíše pozvolný. ${ }^{13}$ Podobný vývoj pak lze vysledovat i ve vztahu k okresům. Ačkoli na úrovni okresů řadu let všeobecná územní státní správa rovněž nepůsobí, oproti starým administrativním krajům byly a jsou okresy jako územně správní jednotka i nadále využívány některými obory specializované státní správy. ${ }^{14}$ Rovněž nelze přehlédnout, že přetrvala jistá tendence některých územních odborných správních úřadů členit se i nadále vnitřně na

7 Srov. ust. $§ 61$ a násl. zákona č. 128/2000 Sb., o obcích (obecní zřízení). Je snad namístě připomenout, že mezi obcemi těchto „stupňư“ ani mezi jejich orgány nepůsobí hierarchické vztahy.

8 Vládní návrh zákona o územně správním členění státu: důvodová zpráva. Sněmovní tisk 395/0, 8. volební období Poslanecké sněmovny PČR. Obecná část, bod 1 [online]. 2019 [cit. 2021-05-31]. Dostupné na: https://www.psp.cz/sqw/historie.sqw?o=8\&T=395. Obdobné důvody ostatně nakonec přispěly k zachování, resp. znovuzavedení okresů i v nové právní úpravě územně správního členění státu.

9 Viz čl. 1 úst. zákona č. 347/1997 Sb. a ust. § 14 zákona č. 36/1960 Sb., o územním členění státu.

10 Jako známý př́klad lze uvést okresy tvořící samosprávný kraj Vysočinu, z nichž okres Pelhřimov současně přináležel administrativnímu Jihočeskému kraji, okres Havlíčkův Brod administrativnímu Východočeskému kraji a okresy Žd'ár nad Sázavou, Jihlava a Třebíč administrativnímu Jihomoravskému kraji.

11 Obvod ORP Tanvald tak například zasahoval do území okresů Jablonec nad Nisou a Semily, jakož i do krajů Severočeského a Východočeského.

$12 \mathrm{~K}$ pojmu mezoregion srov. GROSPIČ, J. a kol. Úvod do regionálních věd a veřejné správy. 2. vyd. Plzeň: Vydavatelství a nakladatelství Aleš Čeněk, 2008, s. 73.

13 Územní finanční orgány se např́iklad novějšímu krajskému uspořádání z roku 2000 přizpůsobily teprve S účinností zákona č. 456/2011 Sb., o Finanční správě České republiky. Analogicky se změnila rovněž struktura celních úřadů, srov. ust. § 6 zákona č. 17/2012 Sb., o Celní správě České republiky.

14 Např. Česká správa sociálního zabezpečení. 
půdorysu okresů, ač v takovém případě přirozeně o zákonné územní působnosti správního úřadu nelze hovořit. 15

\section{HLAVNÍ CÍLE NOVÉ ÚPRAVY ÚZEMNÍHO ČLENĚNÍ STÁTU}

Od návrhu nového zákona si tedy vláda slibovala především zpřehlednění, sjednocení územního členění státu a s nimi ruku v ruce jdoucí zajištění plné skladebnosti jednotlivých úrovní veřejné správy tak, aby se hranice administrativních i samosprávných jednotek různých úrovní územní veřejné správy překrývaly. V tomto ohledu vláda deklarovala záměr zajistit vzájemnou skladebnost územně správních jednotek prostou jakýchkoli výjimek. ${ }^{16}$ Konkrétní kroky k dosažení tohoto cíle byly navrhovatelkou zákona vytyčeny jednak cestou zrušení dosavadního paralelního státně správního územního členění, zavedeného zákonem č. 36/1960 Sb., o územním členění státu, jednak skrze konstituování správních obvodů obcí s rozšířenou působností coby základního stavebního kamene celé hierarchie všeobecné územní státní správy.

Jak plyne z důvodové zprávy, kritika nepřehlednosti dosavadního uspořádání územní veřejné správy vedle domácích zaznívala rovněž z expertních míst Rady Evropy či Organizace pro hospodářskou spolupráci a rozvoj. ${ }^{17}$ Vláda novým zákonem přistoupila k realizaci poslední fáze reformy územní veřejné správy především s ohledem na zjednodušení, a tím i zefektivnění jejího výkonu. Nečinila tak tedy proto, že by byl předchozí stav jakkoli neústavní, v rozporu s mezinárodněprávnými závazky nebo právem Evropské unie. Požadavek přehlednosti a celkové skladebnosti územního členění státu ostatně, jak dále podrobněji pojednáno, nemá výslovný zákonný ani ústavní podklad.

\section{NOVÁ ÚPRAVA DE LEGE LATA}

Nová právní úprava zná v zásadě toliko tři základní úrovně územního členění. Klíčovými jsou správní obvody krajů a správní obvody obcí s rozšířenou působností. ${ }^{18}$ Nelze ovšem zcela opomenout také nejnižší úroveň členění, kterou reprezentuje samo území obce, ${ }^{19}$ pokud jde o výkon přenesené působnosti v základním rozsahu. Tehdy správní obvod obce a území obce spadá v jedno. Území obce jako správní obvod přitom i nadále (nyní již duplicitně) definuje také zákon o obcích. ${ }^{20}$ Zatímco starší výčtový zákon č. 314/2002 Sb. byl v části týkající se obcí s rozšířenou působností zákonem o územním členění zcela nahrazen, soustava obvodů pověřených obecních úřadů v něm vymezená zůstala novým zákonem kupodivu zcela nedotčena. Jedná se tak podle

\footnotetext{
15 Srov. např. vnitřní organizaci územních pracovišt’ krajských hygienických stanic ve smyslu ust. § 82 zákona č. 258/2000 Sb., o ochraně veřejného zdraví.

16 Vládní návrh zákona o územně správním členění státu: důvodová zpráva, s. 3.

17 Tamtéž, s. 4.

18 Ust. § 1 odst. 1 zákona č. 51/2020 Sb., o územně správním členění státu.

19 Ust. § 1 odst. 4 zákona č. 51/2020 Sb., o územně správním členění státu.

20 Ust. § 61 odst. 1 písm. a) zákona č. 128/2000 Sb., o obcích (obecní zřízení).
} 
všeho o jakousi další úroveň územního členění státu, ač zákonem o územně správním členění nepřiznanou. ${ }^{21}$

Nejvyšší článek územního členění podle nové úpravy představují správní obvody krajů, které se na mikroregionální úrovni dále člení na obvody obcí s rozšířenou pưsobností. Lze však vyslovit tezi, že jistým základním kamenem členění jako celku jsou právě tyto „malé okresy“. Teprve výčtem obcí s rozšířenou působností, na něž se obvod kraje podle nového zákona člení, je totiž správní obvod toho kterého kraje definován ${ }^{22}$ a stejně tak nový zákon vymezuje rovněž (tzv. velké) okresy. ${ }^{23}$ Taxativní výčet obcí s rozšířenou působností, dř́ve obsažený v pouhé př́loze zákona č. 314/2002 Sb., touto cestou získal důstojnější umístění prrímo v textu samotného zákona. Teprve stanovení obcí, spadajících do toho kterého obvodu obce III. typu, je ponecháno podzákonnému právnímu předpisu. ${ }^{24}$ Není přitom bez zajímavosti, že oproti územnímu členění z roku 1960 nová úprava zcela opustila stanovení sídla kraje, okresu, resp. správního obvodu obce s rozšriřenou působností, jímž by se implicitně ukládalo zrŕ́dit v něm i sídla správních úřadů působících v témže správním obvodu. ${ }^{25}$ Neznamená to však bez dalšího, že by sídlo správního úruadu místní správy bylo možné stanovit zcela libovolně. Ve vztahu k samosprávným krajům se jejich sídlo například podává již z ústavní úpravy. Stanoví-li pak nový zákon o územním členění právo některých obcí (Černošice, Nýřany aj.) zřídit pracoviště obecního úřadu mimo svůj správní obvod, lze a contrario přinejmenším dovodit, že jinak se obecní úřad musí nacházet vždy uvnitř svého správního obvodu. Nadto o tom, že se obecní úřad zřizuje v obci, jejímž je orgánem, nepochybuje ani komentáŕová literatura, byt' takovou povinnost obecní zř́zení výslovně nestanoví. ${ }^{26}$

Jisté upevnění role „malých okresư“ v novém územním členění státu je nepochybně vedeno rovněž snahou uvést je do souladu s dlouhodobě uplatňovanou regionální politikou posilování přirozených celků, tj. mikroregionů v obvodech obcí s rozšířenou působností a mezoregionů, reprezentovaných vyššími územními samosprávnými celky. Regionální vědy existenci těchto jednotek opírají o analýzu vztahu obyvatelstva $\mathrm{k}$ určitému prostoru, tj. zejména $\mathrm{z}$ hlediska spádovosti center těchto regionů, dojížd'ky za prací, migrace obyvatelstva, fyzickogeografických a dalších ukazatelů. I regionalistika proto právě mikroregiony považuje za tradiční základ struktury administrativního členění státu a staví je do protikladu k členění do větších ekonomicky definovaných celků, jež byly v Československu zavedeny územně správní reformou z roku $1960 .{ }^{27}$

21 Zákonodárce tento postup zdůvodnil skutečností, že vzájemná skladebnost mezi obvody pověřených obcí a obvody obcí s rozšířenou působností existuje již od počátku. Srov. Vládní návrh zákona o územně správním členění státu: důvodová zpráva, s. 14.

22 Ust. § 3 zákona č. 51/2021 Sb., o územně správním členění státu.

23 Ust. § 4 zákona č. 51/2021 Sb., o územně správním členění státu.

24 Ust. § 7 zákona č. 51/2021 Sb., o územně správním členění státu, bylo provedeno vyhláškou Ministerstva vnitra č. 346/2020 Sb.

25 K tomu srov. např̀. ust. § 3 zákona č. 36/1960 Sb., o územním členění státu (ve znění do 31. 12. 2020), podle něhož se ,,vytvářeji tyto kraje: 1. Kraj Středočeský se sídlem v Praze [...]“.

26 Srov např. KOUDELKA, Z. - PRŮCHA, P. - ZWYRTEK HAMPLOVÁ, J. Komentáŕ k § 109. In: Zákon o obcich: komentár. Praha: Leges, 2019.

27 Srov. GROSPIČ, c. d., s. 73. 


\section{OKRESY}

Vedle základního členění, jak napovídá rubrika, nový zákon ovšem dále konstituuje „další územně správní členěni“, jímž se zřizuje staronový systém okresů (v Praze pak analogicky obvodů). ${ }^{28}$ Oproti původnímu uspořádání okresů se alespoň na první pohled nic nemění, nebot' počtem (76) a rovněž stran prostorového uspořádání zůstává mapa okresů s drobnými odchylkami stejná. ${ }^{29} \mathrm{Na}$ rozdíl od jejich historického vymezení prostřednictvím taxativního výčtu přináležejících obcí v sekundární normotvorbě ${ }^{30}$ je okres nově tvořen několika zákonem vyjmenovanými obvody obcí s rozšířenou působností. Př́ípadný přesun některé obce z obvodu „malého“ okresu proto bude bez dalšího znamenat i odpovídající změnu hranice okresu „velkého“ (pokud by byla změnou dotčena), aniž by v soustavě vznikla jakákoli neskladebnost.

Toto další členění v konkurenci se základním územním členěním svádí $\mathrm{k}$ úsudku, že zákonodárce přiznává okresům spíše okrajový význam. Důvodová zpráva se ostatně $\mathrm{k}$ důvodům, proč byly okresy novou úpravou zachovány, odkazuje na skutečnost, že některé správní úřady okresy pro stanovení územní působnosti stále využívají a počítají s nimi také základní registry a řada dalších systémů. V neposlední řadě sám navrhovatel nové úpravy konstatuje, že zrušení okresní struktury by s sebou neslo nutnost velkých zásahů do legislativy, upravující veřejné evidence. ${ }^{31}$ Zachování okresů tedy do značné míry podpořila zcela praktická legislativní hlediska. S okresy se proto napřišstě počítá především jako s evidenčími jednotkami, nikoli však již jako se základem územně správního členění státu. 32

Poukazuje se rovněž na skutečnost, že okresy pro svou organizaci využívá rovněž justice. Je však otázka, nakolik je namístě při výstavbě administrativního územního členění zohledňovat současně organizaci soudní moci, jakkoli státní správu v omezené míre vykonávají i její orgány. Soudní okresy, od nich odvozené soudní kraje a obvody vrchních soudů ostatně vymezuje - nezávisle na obecné úpravě územního členění státu - zákon č. 6/2002 Sb., o soudech a soudcích. ${ }^{33}$ Nelze prritom přehlédnout, že obvody krajských soudů i nadále plně kopírují půdorys starého krajského územního členění státu, veřejnou správou nyní již nadobro opuštěný.

Aniž by se zákonodárce $\mathrm{v}$ důvodové zprávě $\mathrm{k}$ novému zákonu $\mathrm{k}$ takové argumentaci výslovně přihlásil, nepochybně je jedním z klíčových motivů zachování okresů skutečnost, že bez definování jejich území (což nová úprava činí taxativním výčtem obcí s rozšířenou působností), se neobejde organizace vyšších územních samosprávných celků.

28 Ust. § 2 zákona č. 51/2020 Sb., o územně správním členění státu.

29 I nadále existuje na území České republiky 76 okresů a 205 obcí s rozšǐřenou působností, nedochází ani ke změnám jejich názvů. Srov. SLÁMA, D. Nový zákon o územněsprávním členění státu od 1. 1. 2021. Denik veřejné správy [online]. 11. 8. 2020 [cit. 2021-06-22]. Dostupné na: http://www.dvs.cz/clanek .asp?id=6797803.

30 Obce náležející jednotlivým okresům doposud upravovala vyhláška Ministerstva vnitra, kterou se provádělo ustanovení § 1a odst. 3 zákona č. 36/1960 Sb., o územním členění státu (ve znění do 31. 12. 2020).

31 Srov. Vládní návrh zákona o územně správním členění státu: důvodová zpráva, s. 15.

32 Vláda: Zákon o územně správním členění státu nabyl účinnosti. Právní rozhledy. 2021, č. 3, s. 2 [cit. 2021-06-24]. Dostupné na: https://www.beck-online.cz/bo/chapterview-document.seam?documentId= nrptembsgfpxa4s7gnpxgx3jnfya\&groupIndex $=4 \&$ rowIndex $=0$.

33 Srov. ust. § 11 zákona č. 6/2002 Sb., o soudech a soudcích, a jeho př́lohy $1,2,3$. 
Území jednotlivých samosprávných krajů totiž podle prvního článku ústavního zákona o vytvoření vyšších územních samosprávných celků sestává z území tam vypočtených okresů. ${ }^{34}$

\section{6. ÚSTAVNÍ SOUVISLOSTI}

Územnímu státně správnímu členění státu se český ústavní pořádek systematicky nevěnuje a o jeho existenci se nijak nezmiňuje ani třetí hlava Ústavy o moci výkonné. ${ }^{35}$ Tam, kde se tato otázka dotýká práva na (územní) samosprávu, však nelze přehlédnout zřejmé přesahy ústavních pravidel do územního členění. Zvláštní význam mají v tomto ohledu některá ustanovení sedmé hlavy Ústavy, jež působí především k ochraně před zásahy exekutivy do práva obcí a krajů na samosprávu. ${ }^{36}$ Jen zákonem lze proto výkon státní správy svěřit orgánům (územní) samosprávy. Na tento požadavek pak bezprostředně navazuje výhrada zákona i pro př́ípad, že má být územní samosprávný celek (resp. jeho území) správním obvodem. ${ }^{37}$ Pokud tedy nový zákon o územním členění např́ílad v ustanovení $§ 1$ stanoví, že se území České republiky člení na územní obvody krajů, realizuje tak právě článek 100 odst. 1 Ústavy. Správní obvod v takovém prrípadě představuje jednak územní působnost orgánů obcí a krajů, které v něm vykonávají přenesenou působnost, jednak územní působnost př́mých vykonavatelů státní správy, pokud zákonodárce možnosti organizovat správní úřady v týchž obvodech využije. Územní odborné správní úřady takto působí zejména ve správních obvodech samosprávných krajů. ${ }^{38}$ A contrario tedy lze z ústavního pořádku dovodit, že se předpokládá možná existence územního členění, přičemž některé z jeho jednotek splynou s územím územního samosprávného celku a jeho orgány budou mít při výkonu přenesené státní správy stejnou územní působnost. ${ }^{39} \mathrm{~V}$ neposlední řadě je na ústavní úrovni, jak shora zmíněno, prostřednictvím okresů vymezeno území samosprávných krajů. Př́ípadné zrušení okresů by se tedy neobešlo bez zásahu do ústavního pořádku.

Pravidla, jež by omezovala či usměrňovala českého zákonodárce v regulaci vlastního územního členění, přirozeně neplynou ani z práva Evropské unie a zásadně ani z norem mezinárodního práva. Obsahově se otázkám spojeným s územní organizací správy nejvíce přibližují ujednání Evropské charty místní samosprávy (publ. pod č. 181/1999 Sb.). V této souvislosti není zcela bez pochybností otázka, na jaké typy územních jednotek dopadá požadavek článku 5 charty, podle něhož lze hranice místních správních jednotek měnit jen po konzultaci s obyvatelstvem dotčených jednotek. Ovšem vzhledem k tomu,

34 Srov. čl. 1 ústavního zákona č. 347/1997 Sb., o vytvoření vyšších územních samosprávných celků.

35 Není však zcela bez pochybností otázka, na jaké typy územních jednotek dopadá požadavek článku 5 Evropské charty místní samosprávy (publ. pod č. 181/1999 Sb.), podle něhož lze hranice místních správních jednotek měnit jen po konzultaci s obyvatelstvem dotčených jednotek.

$36 \mathrm{~K}$ tomu srov. např. nález Ústavního soudu ze dne 18. 4. 2001, sp. zn. Pl. ÚS 55/2000.

37 Srov. článek 100 odst. 1 větu druhou Ústavy.

38 Srov. např. ust. § 2 odst. 4 zákona č. 359/1992 Sb., o zeměměřických a katastrálních orgánech.

39 K výkladu pojmu ,orgán samosprávy“ ve smyslu článku 105 Ústavy srov. KOPECKÝ, M. Právní postavení obci a krajü: základy komunálního práva. 2. vyd. Praha: C. H. Beck, 2017, s. 191. 
že cílem evropské charty je výhradně garance místní samosprávy, sotva lze její požadavky bez dalšího vztáhnout i na územní organizaci státní správy. ${ }^{40}$

\section{PODMÍNKY ZMĚN HRANIC}

Do územního členění státu ovšem nepřímo promlouvá ústavní ochrana práva na samosprávu rovněž pravidlem, že hranice vyšších územních samosprávných celků lze měnit pouze zákonem..$^{41}$ Mělo-li by proto v budoucnu dojít ke změně hranice obvodu obce s rozšířenou působností, která je současně hranicí okresní a krajskou, bude tak nejspíš třeba učinit prímo zákonem. V této souvislosti se vnucuje otázka, nakolik je vlastně sama obec s to ovlivnit, kterého správního obvodu či vyššího samosprávného celku bude součástí. Zde nelze než konstatovat, že obci se nabízejí spíše než právní především politické nástroje $\mathrm{k}$ prosazení vưle náležet určité územní jednotce, resp. kraji. $\mathrm{K}$ možnostem obce zabránit jejímu přičlenění $\mathrm{k}$ určitému vyššímu uzemnímu samosprávnému celku se ostatně v tomto smyslu vyjádřil i Ústavní soud. ${ }^{42}$ Je jistě namístě připomenout, že podle ustanovení § 15 zákona č. 36/1960 Sb., o územním členění státu (ve znění do 31. 12. 2020), náležela kompetence provádět nepodstatné změny území starých státních administrativních krajů toliko vládě. Až do zř́zení vyšších územních samosprávných celků v roce 2000 nadto stejné ustanovení umožňovalo vládě vedle změn jeho hranic rozhodnout dokonce o samotném zrrízení či zrušení okresu. Forma zákona se tedy i v této oblasti postupně zřetelně prosazuje proti dřívější podzákonné normotvorbě exekutivy, a to i tehdy, srovnáváme-li stávající stav s územní organizací veřejné správy v československé první republice. ${ }^{43}$

\section{ZÁVĚREM}

Připomeňme, že základním cílem přijetí nové právní úpravy územně správního členění státu bylo vytvoření takového systému, který bude dostatečně přehledný a jehož různé úrovně budou vzájemně skladebné. $V$ tomto ohledu jistě došlo ke kýžené změně přinejmenším potud, že nová hierarchie správních obvodů účinně brání dřive ne zcela ojedinělé situaci, kdy určitá obec náležela jinému okresu či státně správnímu kraji, než kam náleží jí př́islušející obec s rozšířenou působností. V tomto směru nelze nevznést námitku, že ani nové uspořádání nezůstalo zcela imunní vůči výjimkám, jež

40 Zatímco v českém překladu charty, v němž byla tato mezinárodní smlouva vyhlášena pod č. 181/1999 Sb., se v článku 5 hovoří o , hranicich mistnich správnich jednotek“, anglický originál smlouvy používá pojem „local authority boundaries “. Pojem ,, local authority“ česká verze překladu přitom má za ,,místní společenstvi “, tj. nepochybně společenství samosprávné.

41 Článek 2 úst. zákona č. 347/1997 Sb., o vytvoření vyšších územních samosprávných celků.

42 Srov. usnesení Ústavního soudu ze dne 15. 3. 2005, sp. zn. III. ÚS 88/05. Vủli zákonodárce nelze přitom z povahy věci zvrátit ani prostřednictvím místního či krajského referenda.

43 Ke změně hranice zastupitelského okresu postačovala vládní nařízení. Předpokladem však bylo dodržení vzájemné skladebnosti celků různé úrovně. Změna zemských hranic pak vyžadovala formu zákona, srov. HOETZEL, J. Československé správní právo: část všeobecná. 2. vyd. Praha: Melantrich, 1937, s. $208-212$. 
si vláda přitom předsevzala zcela vyloučit. Specifický př́pad správního obvodu města Turnov, zasahujícího do tří různých okresů, dal totiž teprve při projednávání nové právní úpravy v poslanecké sněmovně, vládnímu návrhu navzdory, vzniknout ustanovení $§ 7$ odst. 3, podle něhož: „,Ministerstvo vnitra může vyhláškou stanovit, že některé obce náleži do jiného okresu, než do kterého náleži správní obvod obce s rozšiřenou působností, do něhož náleží tyto obce. "Snaha umožnit řešení tohoto ojedinělého problému tak otevřela opět odvozené normotvorbě do budoucna cestu k zakládání nesystémových odchylek, resp. dílčí neskladebnosti. ${ }^{44}$ Kriticky lze jistě nahlížet i skutečnost, že vymezení obvodů obcí s pověřeným obecním úřadem zůstává poněkud nesystémově ponecháno i nadále ve zvláštní úpravě, 45 jakkoli platí, že změny dosažené novým zákonem o územně správním členění se struktury tzv. pověřených obcí nedotýkají.

Pomineme-li však nedostatky, které nutně doprovázejí každý reformní legislativní krok, lze předně ocenit, že se realizaci jednotného územního členění státu podařilo dotáhnout do zdárného konce, když předešlé vládní pokusy nezaznamenaly úspěch.46 Z obecných hledisek organizace veřejné správy je však zdaleka nejpodstatnějším přínosem přizpůsobení administrativního územního členění smíšenému modelu veřejné správy. Nový zákon tak respektuje skutečnost, že na některých úrovních územní veřejné správy spadá správní obvod v jedno s územím územního samosprávného celku a současně odbourává zcela nadbytečnou a historicky překonanou soustavu sedmi administrativních krajů. Pojem kraj tak napříště neponese dva různé významy. V neposlední řadě je třeba vyzdvihnout, že nový zákon systém všeobecného územně správního členění sjednotil, aniž by bylo zapotřebí jeho zásadní a náročné reorganizace. To lze dobře demonstrovat na zvoleném řešení otázky nové úlohy okresů, jež bylo rozumné z mnoha praktických důvodů ponechat, byt' spíše v roli jakéhosi podpůrného mezičlánku celé soustavy. ${ }^{47}$ Zachování potřebné kontinuity územního členění, úroveň okresů nevyjímaje, ostatně svědčí - vedle veřejné správy samotné - především jejím adresátům.

JUDr. Martin Wagner

Právnická fakulta Univerzity Karlovy

wagnerm@prf.cuni.cz

44 Viz Vládní návrh zákona o územně správním členění státu: pozměňovací a jiné návrhy. Sněmovní tisk 395/4, 8. volební období Poslanecké sněmovny PČR [online]. 2019 [cit. 2021-06-28]. Dostupné na: https:// www.psp.cz/sqw/historie.sqw?o=8\&t=395.

45 Viz zákon č. 314/2002 Sb., o obcích s pověřeným obecním úřadem.

46 BAHÝLOOVÁ, L. - FILIP, J. - MOLEK, P. a kol. Ústava České republiky: komentář. Praha: Linde, 2010, s. 1390.

47 Není bez zajímavosti, že krátce po nabytí účinnosti zákona č. 51/2021 Sb., o územně správním členění státu, vláda staronové okresní uspořádání využila k realizaci krizových opatření ke zvládání šiření epidemie. K tomu srov. např. usnesení vlády č. 134 (publ. pod č. 68/2021 Sb.), o přijetí krizového opatř̌ení k omezení volného pohybu osob na území okresů Cheb, Sokolov a Trutnov. 